\title{
Effect of Phospholipase Digestion and Lysophosphatidylcholine on Dopamine Receptor Binding
}

\author{
C. R. Oliveira, E. P. Duarte, and A. P. Carvalho \\ Center for Cell Biology, Department of Zoology, and Neurological Clinic, Universidade de Coimbra, \\ Coimbra, Portugal
}

\begin{abstract}
H}\right]$ Spiperone specific binding by microsomal membranes isolated from sheep caudate nucleus is decreased by trypsin and phospholipase $\mathrm{A}_{2}$ (Vipera russeli), but is insensitive to neuraminidase. The inhibitory effect of phospholipase $A_{2}$ is correlated with phospholipid hydrolysis. After $15 \mathrm{~min}$ of phospholipase $(5 \mu \mathrm{g} / \mathrm{mg}$ protein) treatment, a maximal effect is observed; the maximal lipid hydrolysis is about $56 \%$ and produces $82 \%$ reduction in $\left[{ }^{3} \mathrm{H}\right]$ spiperone binding. Equilibrium binding studies in nontreated and treated membranes showed a reduction in $B_{\max }$ from a value of $388 \pm 9.2 \mathrm{fmol} / \mathrm{mg}$ protein before phospholipase treatment to a value of $52 \pm 7.8 \mathrm{fmol} / \mathrm{mg}$ protein after treatment, but no change in affinity $\left(K_{\mathrm{D}}=\right.$ $0.24 \pm 0.042 \mathrm{nM}$ ) was observed. Albumin washing of treated membranes removes $47 \%$ of lysophosphatidylcholine produced by phospholipid hydrolysis without recovering $\left[{ }^{3} \mathrm{H}\right]$ spiperone binding activity. However, the presence of $2.5 \%$ albumin during phospholipase $\mathrm{A}_{2}$ action $(1.5 \mu \mathrm{g} / \mathrm{mg}$ protein) prevents the inhibitory effect of phospholipase on $\left[{ }^{3} \mathrm{H}\right]$ spiperone binding to the membranes,
\end{abstract}

although $28 \%$ of the total membrane phospholipid is hydrolysed. Lysophosphatidylcholine, a product of phospholipid hydrolysis, mimics the phospholipase $\mathrm{A}_{2}$ effect on receptor activity, but the $\left[{ }^{3} \mathrm{H}\right]$ spiperone binding inhibition can be reversed by washing with $2.5 \%$ defatted serum albumin. Addition of microsomal lipids to microsomal membranes pretreated with phospholipase does not restore $\left[{ }^{3} \mathrm{H}\right]$ spiperone stereospecific binding. It is concluded that the phospholipase-mediated inhibition of $\left[{ }^{3} \mathrm{H}\right]$ spiperone binding activity results not only from hydrolysis of membrane phospholipids, but also from an alteration of the lipid environment by the end products of phospholipid hydrolysis. Key Words: $\left[{ }^{3} \mathrm{H}\right]$ Spiperone specific binding-Phospholipase $\mathrm{A}_{2}-$ Phospholipid hydrolysis-Lysophosphatidylcholine-Albumin effectEndogenous lipids addition. Oliveira C. R. et al. Effect of phospholipase digestion and lysophosphatidylcholine on dopamine receptor binding. J. Neurochem. 43, 455465 (1984).
The dopamine receptor is believed to be a membrane receptor embedded within the lipid bilayer (Laduron and Ilien, 1982; Leysen and Van Gompel, 1982). The intimate contact of the receptor with the membrane lipids makes it possible for the structural and physical properties of the membrane lipids to affect the binding characteristics of the receptor, as was shown for several receptor systems; e.g., the serotonin receptor (Heron et al., 1980), the nicotinic receptor (Chang and Bock, 1979; Heidmann et al., 1980), the tetrodotoxin binding sites (Agnew and Raftery, 1979; Reed, 1981), the $\beta$-adrenergic re- ceptor (Bakardjieva et al., 1979), and the gonadotropin receptors (Azhar and Menon, 1976; Azhar et al., 1976). Furthermore, the $\beta$-adrenergic-receptormediated stimulation of adenylate cyclase activity is affected by membrane lipid alterations (Limbird and Lefkowitz, 1976). Thus, by altering either the receptor-agonist interaction or the coupling of the receptor with the adenylate cyclase, membrane lipids modulate receptor activity.

The nature of membrane receptors and their interactions with other membrane components can usefully be studied by degrading specifically the
Received June 20, 1983; revised October 28, 1983; accepted January 19, 1984.

Address correspondence and reprint requests to $\mathrm{C}$. R. Oliveira, Department of Zoology, Universidade de Coimbra, 3049 Coimbra Codex, Portugal.
Abbreviations used: TAN, $15 \mathrm{mM}$ Tris- $\mathrm{HCl}, \mathrm{pH} 7.4,1.1 \mathrm{mM}$ ascorbic acid, $12.5 \mu M$ nialamide; TEAN, $15 \mathrm{~m} M$ Tris $-\mathrm{HCl}, 5$ $\mathrm{m} M \mathrm{Na}_{2}$-EDTA, $1.1 \mathrm{~m} M$ ascorbic acid, $12.5 \mu M$ nialamide, $\mathrm{pH}$ 7.4 . 
membrane phospholipids and following the consequent alterations in receptor activity. In this study, caudate nucleus microsomal membranes were treated with trypsin, with neuraminidase, and with phospholipase $A_{2}$. The resulting changes in $\left[{ }^{3} \mathrm{H}\right]$ spiperone binding activities and the phospholipid composition of the membranes were examined. The extent of phospholipid hydrolysis was measured and correlated with $\left[{ }^{3} \mathrm{H}\right]$ spiperone binding activity. The role of added endogenous lipids and of products of lipid hydrolysis on the regulation of $\left[{ }^{3} \mathrm{H}\right]$ spiperone binding to dopamine receptors was also investigated.

\section{MATERIALS AND METHODS}

Preparation of sheep caudate microsomal fraction Sheep brains were obtained fresh, and their caudate nuclei were removed within $1 \mathrm{~h}$ after death and fractionated by the method described by Hajós (1975). The caudate nucleus was added to cold sucrose at an approximate concentration of $1.0 \mathrm{~g}$ wet weight per $9.0 \mathrm{ml}$ of $0.3 \mathrm{M}$ sucrose and was homogenized in a glass homogenizer with a Teflon piston. The supernatants obtained after centrifugation at $1,500 \times g$ for $10 \mathrm{~min}$ were centrifuged at $9,000 \times g$ for $20 \mathrm{~min}$. The supernatants obtained were collected and centrifuged at $39,000 \times g$ for $30 \mathrm{~min}$ at $4^{\circ} \mathrm{C}$. The pellets were resuspended in $15 \mathrm{mM}$ Tris- $\mathrm{HCl}(\mathrm{pH}$ 7.4), $1.1 \mathrm{mM}$ ascorbic acid, $12.5 \mu M$ nialamide (TAN buffer) at $4^{\circ} \mathrm{C}$, and were washed twice with the same buffer. The final resuspension was in a volume of TAN buffer to obtain a protein concentration of $6 \mathrm{mg} / \mathrm{ml}$, as determined by the biuret method (Layne, 1957). The microsomal fraction was stored in $2-\mathrm{ml}$ aliquots at $-20^{\circ} \mathrm{C}$ for future use.

\section{$\left[{ }^{3} \mathrm{H}\right]$ Spiperone binding assay}

$\left[{ }^{3} \mathrm{H}\right]$ Spiperone binding to microsomal membranes was measured in an incubation mixture (final volume of 0.6 $\mathrm{ml}$ ) consisting of $0.2 \mathrm{ml}$ membrane preparation $(0.1-0.2$ $\mathrm{mg}$ protein) and $0.2 \mathrm{ml} \mathrm{TEAN} \mathrm{buffer} \mathrm{(} 15 \mathrm{mM}$ Tris- $\mathrm{HCl}, 5$ $\mathrm{m} M \mathrm{Na}_{2}$-EDTA, $1.1 \mathrm{~m} M$ ascorbic acid, $12.5 \mu M$ nialamide, pH 7.4) (Seeman et al., 1975; Leysen et al.. 1978). To define specific and stereospecific binding, $(+)$ or (-)-butaclamol $\left(10^{-6} M\right.$ final concentration) was added. The samples were incubated for $45 \mathrm{~min}$ at $25^{\circ} \mathrm{C}$, and the reaction was terminated by rapid filtration under vacuum of $0.5-\mathrm{ml}$ aliquots through glass fiber filters (Whatman GF/B). The filter was washed with $10 \mathrm{ml}$ of TEAN buffer at room temperature. Radioactivity was counted by liquid scintillation spectrometry in a Packard scintillation counter, Model $450 \mathrm{C}$, corrected for quenching, after overnight equilibration in $8.0 \mathrm{ml}$ Triton X-100 scintillation fluid (Pasternak and Snyder, 1974). Specific and stereospecific binding were defined as the difference between the amount of $\left[{ }^{3} \mathrm{H}\right]$ spiperone bound in the absence or in the presence of $(-)$-butaclamol and that in the presence (nonspecific binding) of $10^{-6} M(+)$ butaclamol. The amount of $\left[{ }^{3} \mathrm{H}\right]$ spiperone bound was expressed as fmol of $\left[{ }^{3} \mathrm{H}\right]$ spiperone bound $/ \mathrm{mg}$ of protein. All the assays were done in triplicate and the results were replicated at least three times in independently performed experiments.

\section{Treatment of membranes with trypsin}

Microsomal membrane suspensions containing $10 \mathrm{mg}$ protein $/ \mathrm{ml}$ were incubated with trypsin (10 $\mu \mathrm{g}$ of trypsin/ $\mathrm{mg}$ of protein) in TAN buffer, $\mathrm{pH} 7.4(5.0 \mathrm{ml}$ final volume), at $25^{\circ} \mathrm{C}$, with gentle stirring. The reaction was initiated by adding trypsin, and 1.0-ml aliquots were taken at different times. The digestion was stopped by adding soy bean trypsin inhibitor ( $2 \mathrm{mg}$ of trypsin inhibitor/mg of trypsin), and the samples were stored in ice. After centrifugation at $100,000 \times g$ for $1 \mathrm{~h}$, the pellets were resuspended in TEAN buffer, $\mathrm{pH} 7.4$, at $4^{\circ} \mathrm{C}$, and were used directly for binding assays (Leysen and Van Gompel, 1982). Protein concentration in the pellets was determined by the biuret method (Layne, 1957).

\section{Treatment of membranes with neuraminidase}

Microsomal membrane suspensions $(10 \mathrm{mg} / \mathrm{ml}$ of protein) were incubated with neuraminidase $(4 \mu \mathrm{g} / \mathrm{mg}$ of protein) in TAN buffer, $\mathrm{pH} 7.4$, at $37^{\circ} \mathrm{C}$, in a final volume of $5.0 \mathrm{ml}$. Aliquots were taken at convenient intervals for $30 \mathrm{~min}$, and were chilled in ice. The samples were centrifuged as described above and the final pellets were resuspended in TEAN buffer, assayed for protein (Layne, 1957), and used for binding assays.

\section{Treatment of membranes with phospholipase $A_{2}$}

Aliquots of microsomal membranes were incubated with phospholipase $\mathrm{A}_{2}$, Vipera russeli (see legends of figures for protein and enzyme concentrations), in $25 \mathrm{mM}$ Tris-maleate, $\mathrm{pH} 7.0$, in the presence of $2 \mathrm{mM} \mathrm{CaCl}$, and $10 \mu M$ of phenylmethylsulphonyl fluoride at $30^{\circ} \mathrm{C}$, with agitation. Aliquots were removed at different times, and the digestion was stopped by adding $4 \mathrm{~m} M$ EGTA and chilling the sample in ice. The membranes were recovered by centrifugation at $100,000 \times g$ for $1 \mathrm{~h}$. The pellets were resuspended in a solution containing $3 \%$ bovine serum albumin, fatty acid free, in $10 \mathrm{~m} M$ Tris-maleate $(\mathrm{pH}$ 7.0) and washed twice, the first time with $10 \mathrm{ml}$ of the albumin solution and the second time with an excess of $10 \mathrm{~m} M$ Tris-maleate ( $\mathrm{pH} 7.0$ ). The pellets were further suspended in TEAN buffer, $\mathrm{pH} 7.4$, and were assayed for protein concentration, phospholipid composition, and $\left[{ }^{3} \mathrm{H}\right]$ spiperone binding activity.

\section{Treatment of membranes \\ with lysophosphatidylcholine}

Aliquots of membranes ( $1 \mathrm{mg}$ of protein/ml) were incubated with increasing concentrations of lysophosphatidylcholine in a final volume of $3.6 \mathrm{ml}$ of $25 \mathrm{mM}$ Trismaleate ( $\mathrm{pH} 7.0$ ) containing $2 \mathrm{mM} \mathrm{CaCl}$, at $30^{\circ} \mathrm{C}$, for 15 min, with agitation. After incubation, EGTA was added to each tube to a final concentration of $4 \mathrm{mM}$. The samples were cooled in ice, and the membranes were recovered by centrifugation at $100,000 \times g$ for $1 \mathrm{~h}$. The sedimented membranes were then analysed for their $\left[{ }^{3} \mathrm{H}\right]$ spiperone binding activity and protein concentration. The supernatants were assayed for protein concentration and for soluble dopamine receptors using a charcoal adsorption method, as will be described. Protein concentrations were determined by the method of Lowry et al. (1951). 
Treatment of $\left[{ }^{3} \mathbf{H}\right]$ spiperone-receptor complex from microsomal membranes with phospholipase $\mathrm{A}_{2}$

Microsomal membranes ( $20 \mathrm{mg}$ of protein) were incubated in a final volume of $10 \mathrm{ml}$ of TAN buffer $(\mathrm{pH} 7.4)$ containing $2 \mathrm{mM} \mathrm{CaCl}, 1 \mathrm{mM} \mathrm{MgCl}_{2}, 100 \mathrm{mM} \mathrm{NaCl}, 5$ $\mathrm{m} M \mathrm{KCl}$ with $\left[{ }^{3} \mathrm{H}\right]$ spiperone $(2 \mathrm{nM})$ at $25^{\circ} \mathrm{C}$ for $45 \mathrm{~min}$. Incubation for nonspecific binding was performed in parallel in the presence of $10^{-6} M(+)$-butaclamol or (-)butaclamol. After incubation, the prelabelled membranes were treated with phospholipase $A_{2}(5 \mu \mathrm{g} / \mathrm{mg}$ of protein) at $30^{\circ} \mathrm{C}$ for $15 \mathrm{~min}$, with gentle stirring. Digestion was inhibited by adding $4 \mathrm{~m} M$ EGTA and chilling the samples in ice. The samples were centrifuged at $100,000 \times g$ for $1 \mathrm{~h}$, and aliquots $(0.4 \mathrm{ml})$ of the supernatants were used for the determination of soluble dopamine receptor by the charcoal adsorption method and for protein determination. The pellets were resuspended in $10 \mathrm{mM}$ Tris-maleate, $\mathrm{pH} 7.0$, and washed as described above. The final

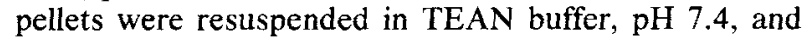
were analysed for protein concentration. Radioactivity remaining in the pellets was assayed by the filtration method as described previously (Seeman et al., 1975).

\section{Charcoal adsorption method for soluble receptor determination}

Solubilized extracts $(0.4 \mathrm{ml})$ were added to Eppendorf microfuge tubes containing $\left[{ }^{3} \mathrm{H}\right]$ spiperone (1 $\mathrm{n} M$ final concentration) and TEAN buffer, $\mathrm{pH} \mathrm{7.4,} \mathrm{or} \mathrm{(+)-} \mathrm{or} \mathrm{(-)-}$ butaclamol $\left(10^{-6} M\right.$ final concentration), in a final volume of $0.5 \mathrm{ml}$. Samples were incubated for 6 or $16 \mathrm{~h}$ in ice, and free ligand was separated from bound by adsorption to dextran-coated charcoal $(2.5 \%$ charcoal, $0.25 \%$ dextran in TEAN buffer, $\mathrm{pH} 7.4$ ) for $20 \mathrm{~min}$ with stirring (Wheatley and Strange, 1983). Charcoal suspensions were pelleted using an Eppendorf microcentrifuge at $9,980 \times g$ for $5 \mathrm{~min}$. An aliquot of the supernatant $(0.3$ $\mathrm{ml}$ ) was collected as the bound species and counted in $8.0 \mathrm{ml}$ Triton X-100 scintillation fluid (Pasternak and Snyder, 1974) by liquid scintillation spectrometry, after overnight equilibration.

\section{Lipid extraction and thin-layer chromatography}

Lipids were extracted from untreated and phospholipase $A_{2}$-treated membranes ( $5 \mathrm{mg}$ of protein) in $\mathrm{CHCl}_{3}: \mathrm{CH}_{3} \mathrm{OH}$ mixtures (Reed et al., 1960), which were evaporated under low pressure in a rotatory evaporator, and the extracts were freed of water by washing with toluene which was evaporated to dryness under nitrogen. Aliquots of lipid extract dissolved in $\mathrm{CHCl}_{3}$ were then analysed for total lipid phosphorus (Bartlett, 1959), cholesterol content (Huang et al., 1961), and phospholipid composition. Lipid samples were separated on thin-layer plates of silica gel $\mathrm{G}$ (Merck) using as solvent a mixture of $\mathrm{CHCl}_{3}: \mathrm{CH}_{3} \mathrm{OH}: \mathrm{H}_{2} \mathrm{O}(65: 25: 4, \mathrm{vol} / \mathrm{vol})$. Individual phospholipids were identified using group-specific spray reagents (Skipski and Barclay, 1969) and by co-chromatography with lipid standards (Supelco, PA, U.S.A.). For quantitative estimation of resolved phospholipids the thin-layer plates were exposed to iodine vapor, the yellow stained spots were marked, the iodine was evaporated, and the individual spots were scraped from the plate. The amount of each phospholipid was determined by mea- suring the amount of inorganic phosphate in the scraped spots previously digested in $70 \% \mathrm{HClO}_{4}$ (Böttcher et al., 1961).

\section{Preparation of liposomes}

Multilamellar liposomes were prepared with lipids isolated from the microsomal fraction of the caudate nucleus (Bangham et al., 1967). The desired amount of lipid $(0.4$ $\mathrm{mg}$ per test tube), determined by a phosphorus assay according to Bartlett (1959), was taken from the chloroform solution, and the solvent was evaporated first in a nitrogen stream and then under vacuum for $3 \mathrm{~h}$. Buffer solution (TEAN, $\mathrm{pH}$ 7.4) and several glass beads were added and vortexed for $3 \mathrm{~min}$ at room temperature. The same buffer was used in binding assays, performed at $37^{\circ} \mathrm{C}$ for $15 \mathrm{~min}$ in the absence and in the presence of $(+)$ and (-)-butaclamol, as described above.

\section{Reconstitution of $\left[{ }^{3} \mathrm{H}\right]$ spiperone binding by endogenous lipids}

The dry lipid extract from microsomal membranes (7 $\mathrm{mg}$ of phospholipid) was suspended in a buffer solution (2.0 ml of TEAN buffer, $\mathrm{pH} \mathrm{7.4)} \mathrm{and} \mathrm{was} \mathrm{sonicated} \mathrm{for}$ $30 \mathrm{~min}$ in a sonifier bath, at a temperature of $10-15^{\circ} \mathrm{C}$ (Huang and Thompson, 1974). The liposomes so prepared were centrifuged at $100,000 \times g$ for $30 \mathrm{~min}$. The supernatants were carefully removed and were incubated with aliquots of untreated and phospholipase $\mathrm{A}_{2}$-treated membranes (phospholipid/protein ratio of $8: 4 \mathrm{mg}$ ) at $37^{\circ} \mathrm{C}$ for $10 \mathrm{~min}$. After incubation the samples were centrifuged in an excess of TEAN buffer $(\mathrm{pH} 7.4)$ at $100,000 \times g$ for 30 min. The membranes with bound phospholipid sedimented, whereas the unbound phospholipids remained in the supernatant. $\left[{ }^{3} \mathrm{H}\right]$ Spiperone binding, phospholipids bound to the membranes, and protein concentration were determined as described previously.

\section{Materials}

All the enzymes used for this study were obtained from Sigma Chemical (St. Louis, MO). $\left[{ }^{3} \mathrm{H}\right]$ Spiperone with a specific activity of $25 \mathrm{Ci} / \mathrm{mmol}$ was obtained from the Radiochemical Center (Amersham, U.K.), and butaclamol was kindly donated by Ayerst Research Laboratories (Canada).

\section{RESULTS}

Effects of neuraminidase, trypsin, and phospholipase $A_{2}$ on $\left[{ }^{3} \mathrm{H}\right]$ spiperone specific binding to caudate nucleus microsomal membranes

The effect of treating the microsomal membranes with neuraminidase, trypsin, or phospholipase $A_{2}$ on $\left[{ }^{3} \mathrm{H}\right]$ spiperone specific binding was examined (Fig. 1A and B). Digestion of the microsomal membranes as a function of time causes a rapid initial loss of $\left[{ }^{3} \mathrm{H}\right]$ spiperone specific binding to the membranes during the first $5 \mathrm{~min}$, and at a slower rate thereafter (Fig. 1A). After digestion of the membranes and centrifugation at $100,000 \times g$ for $1 \mathrm{~h}$, the amount of protein recovered in the sediment is 
A

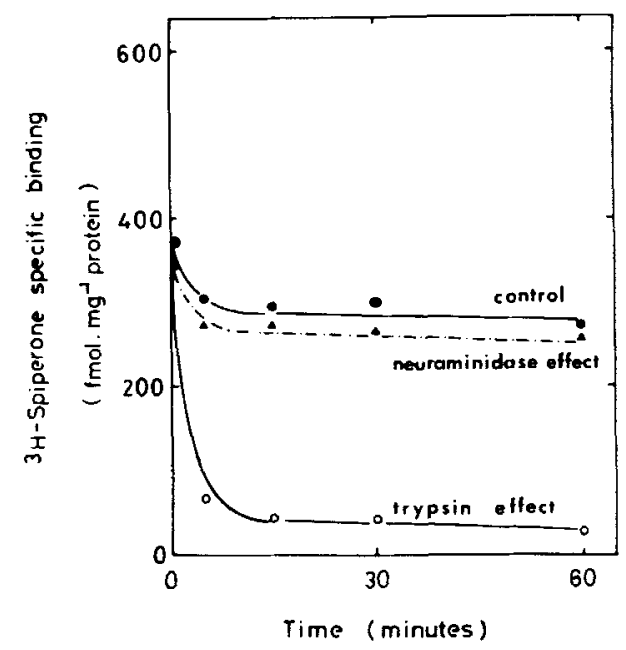

B

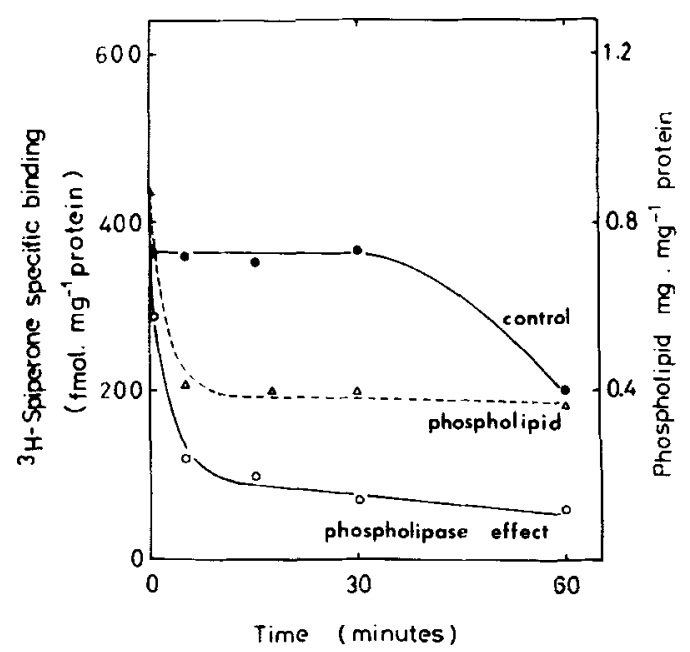

FIG. 1. Effect of enzymatic treatments on $\left[{ }^{3} \mathrm{H}\right]$ spiperone specific binding to caudate nucleus microsomal membranes. Microsomal membranes (10 $\mathrm{mg} / \mathrm{ml}$ of protein) were treated with trypsin $(10 \mu \mathrm{g}$ of trypsin $/ \mathrm{mg}$ protein), neuraminidase (4 $\mu \mathrm{g} / \mathrm{mg}$ of protein) (A), or phospholipase $A_{2}(5 \mu \mathrm{g} / \mathrm{mg}$ protein) (B), as described under Materials and Methods. Aliquots of the membrane suspensions were removed at convenient intervals of up to $1 \mathrm{~h}$ and assayed for $\left[{ }^{3} \mathrm{H}\right]$ spiperone binding and phospholipid content. Assay conditions were as described in Materials and Methods. The concentration of $\left[{ }^{3} \mathrm{H}\right]$ spiperone was $0.26 \mathrm{nM}$ and that of protein was $0.2 \mathrm{mg}$ per test tube. No change in the phospholipid content of control membranes was observed. Values are means of triplicate determinations in a representative of three experiments with standard errors varying less than $\pm 6 \%$.

decreased as compared to the control values, but the amount of protein lost could not account for the loss in specific binding even if the membrane proteins were randomly solubilized.

Phospholipase $\mathrm{A}_{2}$ also reduces $\left[{ }^{3} \mathrm{H}\right]$ spiperone specific binding, lowering it by $68 \%$ after $5 \mathrm{~min}$ digestion of the membranes, but the extent of binding inhibition increases slowly with longer digestion periods (Fig. 1B). The progressive loss of specific binding of $\left[{ }^{3} \mathrm{H}\right]$ spiperone to the membranes, which results with increasing time of phospholipase $\mathrm{A}_{2}$ treatment, correlates well with the extent of phospholipid hydrolysis (Fig. 1B).

In contrast to the very potent effects of trypsin and phospholipase $A_{2}$, neuraminidase has only a negligible effect on $\left[{ }^{3} \mathrm{H}\right]$ spiperone specific binding. To assess whether phospholipase $A_{2}$ treatment alters the total number of receptor sites or their affinity or both, we measured the ability of microsomal membranes to bind $\left[{ }^{3} \mathrm{H}\right]$ spiperone at various concentrations of free $\left[{ }^{3} \mathrm{H}\right]$ spiperone after phospholipase $A_{2}$ treatment $(5 \mu \mathrm{g} / \mathrm{mg}$ protein for $30 \mathrm{~min}$ ). Binding analysis was carried out on control untreated membranes and on phospholipase-treated membranes after albumin washing. From Scatchard analysis of the data, it is clear that the apparent dissociation constant $\left(K_{\mathrm{D}}\right)$ is virtually unchanged by the enzyme treatment, but there is a large reduction of the maximal number of binding sites $\left(B_{\max }\right)$ (Fig. 2) from a value of $388 \mathrm{fmol} / \mathrm{mg}$ protein in control membranes to a value of $52 \mathrm{fmol} / \mathrm{mg}$ protein after lipid digestion of the membranes.
Relationship between phospholipid hydrolysis and $\left[{ }^{3} \mathrm{H}\right]$ spiperone binding activity

The effect of varying the concentration of phospholipase $\mathrm{A}_{2}$, Vipera russeli, on the specific and stereospecific binding of $\left[{ }^{3} \mathrm{H}\right]$ spiperone to the microsomal membranes is shown in Fig. 3. $\left[{ }^{3} \mathrm{H}\right]-$ Spiperone stereospecific binding is almost completely lost by treatment of $1 \mathrm{mg}$ protein containing membranes with about $5 \mu \mathrm{g}$ of enzyme, at $30^{\circ} \mathrm{C}$, for $5 \mathrm{~min}$. Again, there is a striking correlation between phospholipid hydrolysis and loss of $\left[{ }^{3} \mathrm{H}\right]$ spiperone specific and stereospecific binding with increasing concentrations of the enzyme (Fig. 3). Most of the $\left[{ }^{3} \mathrm{H}\right]$ spiperone stereospecific binding is lost when only $34 \%$ of the phospholipid is hydrolysed, and this binding activity is completely lost at about $50 \%$ hydrolysis of the membrane phospholipids. At this level of hydrolysis, phosphatidylcholine, phosphatidylserine, and phosphatidylethanolamine are hydrolysed, but not the sphingomyelin (Table 1). Phosphatidylethanolamine and phosphatidylcholine are extensively hydrolysed, and the lysophosphatidylcholine formed by the action of phospholipase $\mathrm{A}_{2}$ on the membrane phospholipids is not completely removed from the membrane by washing it with a medium containing 2.5\% albumin (Table 1, Fig. 4).

\section{Effects of free fatty acids and lysophospholipids on $\left[{ }^{3} \mathrm{H}\right]$ spiperone binding to microsomal membranes}

The decrease of $\left[{ }^{3} \mathrm{H}\right]$ spiperone specific binding by phospholipase $\mathrm{A}_{2}$ treatment of the membranes 


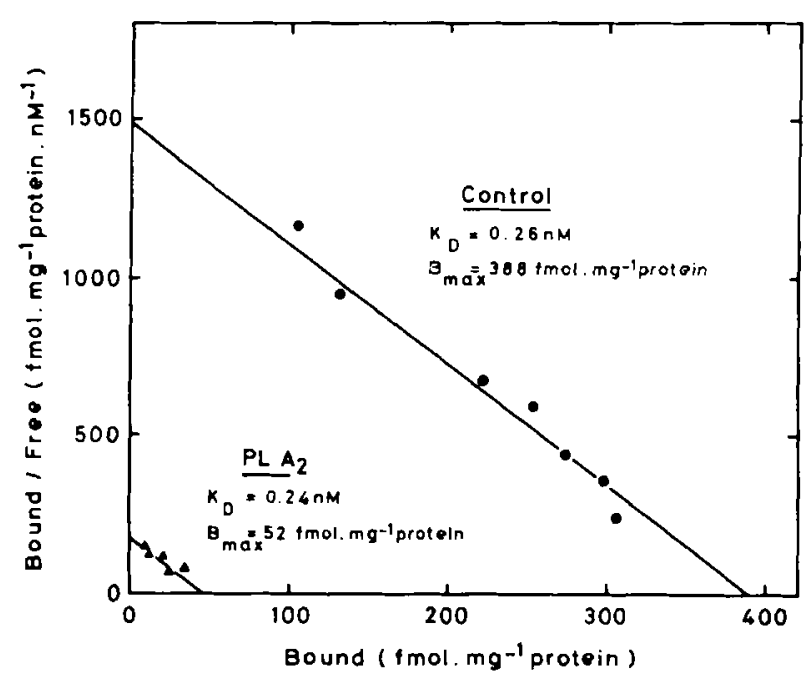

FIG. 2. Scatchard plot of $\left[{ }^{3} \mathrm{H}\right]$ spiperone specific binding to phospholipase $\mathrm{A}_{2}$-treated membranes. Caudate nucleus microsomal membranes were incubated with phospholipase $A_{2}$ $(5 \mu \mathrm{g} / \mathrm{mg}$ of protein) in $25 \mathrm{mM}$ Tris-maleate buffer $(\mathrm{pH} 7.0)$ in the presence of $2 \mathrm{mM} \mathrm{CaCl}$, at $37^{\circ} \mathrm{C}$, for $30 \mathrm{~min}$. Control membranes were incubated in the same conditions, except for phospholipase $A_{2}$ addition. After incubation, the membranes were sedimented and washed as described under Materials and Methods. Final pellets, resuspended in TEAN buffer $(\mathrm{pH} 7.4)$ at a protein concentration of $1 \mathrm{mg} / \mathrm{ml}$, were assayed for $\left[{ }^{3} \mathrm{H}\right]$ spiperone binding at concentrations from 2 $\mathrm{nM}$ to $0.12 \mathrm{nM}$, in the presence and in the absence of $1 \mu M$ (+)-butaclamol. All points in the figure are means of triplicate determinations from one of three experiments. Values calculated for $K_{\mathrm{D}}=0.24 \pm 0.042 \mathrm{nM}$ and for $B_{\max }=52 \pm$ $7.8 \mathrm{fmol} / \mathrm{mg}$ protein in phospholipase $A_{2}$-treated membranes $(\Lambda-\Lambda)$, as compared to the control values of $K_{\mathrm{D}}=0.26 \pm$ $0.014 \mathrm{nM}$ and $B_{\max }=388 \pm 9.2 \mathrm{fmol} / \mathrm{mg}$ protein $(\longrightarrow)$

could result from the accumulation in the membrane of the phospholipid hydrolysis products, namely fatty acids and lysophospholipids. In order to test this possibility, the phospholipase-treated

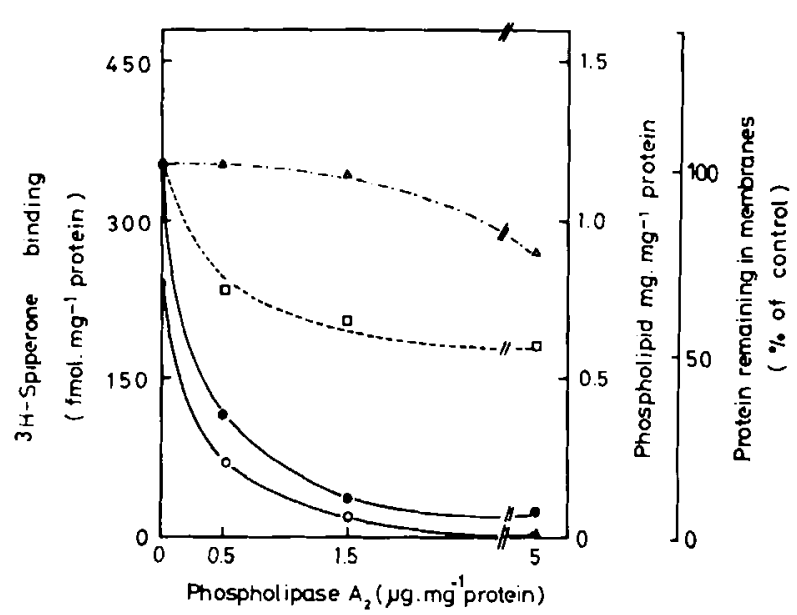

FIG. 3. Effects of varying concentrations of phospholipase $\mathrm{A}_{2}$ (Vipera russeli) on [ ${ }^{3} \mathrm{H}$ ]spiperone binding and on the extent of phospholipid hydrolysis of caudate nucleus microsomal membranes. Aliquots $(1 \mathrm{mg} / \mathrm{ml}$ protein) of membrane preparations were incubated with increasing concentrations of phospholipase $A_{2}$ in $25 \mathrm{mM}$ Tris-maleate $(\mathrm{pH} \mathrm{7.0)}$ in the presence of $2 \mathrm{mM} \mathrm{CaCl}_{2}$, at $30^{\circ} \mathrm{C}$, for $5 \mathrm{~min}$. The phospholipase $A_{2}$ reaction was stopped by adding EGTA to a final concentration of $4 \mathrm{mM}$. The membranes were then washed and assayed for $\left[{ }^{3} \mathrm{H}\right]$ spiperone binding $(0.2 \mathrm{nM})$ in the presence of $10^{-6} M(+)$ - or (-)-butaclamol, and for total lipid phosphorus. The values are means of triplicate determinations from one representative experiment with standard errors varying less than $\pm 6 \%$. Symbols: $0-0$, stereospecific binding; $\square-\cdots$, total lipid phosphorus (mg phospholipids $\cdot \mathrm{mg}^{-1}$ protein); $\triangle \cdots-\cdots, \Delta$, protein remaining in the pellet, as a percentage of control.

membranes were washed with a medium containing $2.5 \%$ fatty-acid-free bovine serum albumin. Parallel experiments were also performed in which albumin was included in the incubation medium simultaneously with phospholipase $A_{2}$. The results are shown in Table 2.

TABLE 1. Hydrolysis of membrane phospholipids by phospholipase $A_{2}$

\begin{tabular}{|c|c|c|c|}
\hline & \multicolumn{2}{|c|}{$\begin{array}{l}\text { Membrane phospholipid content } \\
\text { (mg } \cdot \mathrm{mg}^{-1} \text { protein) }\end{array}$} & \multirow[b]{2}{*}{$\%$ Hydrolysis } \\
\hline & $\begin{array}{l}\text { Native } \\
\text { membranes }\end{array}$ & $P L A_{2}$-treated & \\
\hline Total phospholipid & $0.921 \pm 0.057$ & $0.485 \pm 0.045$ & $50 \pm 4.24$ \\
\hline Sphingomyelin & $0.085 \pm 0.011$ & $0.091 \pm 0.016$ & 0 \\
\hline Phosphatidylcholine + & & - & 70 \\
\hline Phosphatidylethanolamine & $\begin{array}{l}0.486 \pm 0.005 \\
0.296 \pm 0.017\end{array}$ & $\begin{array}{l}0.254 \pm 0.044 \\
0.163 \pm 0.016\end{array}$ & $\begin{array}{l}51 \pm 7.8 \\
48 \pm 5.66\end{array}$ \\
\hline Lysophosphatidylcholine & N.D. & $\begin{array}{c}0.098 \pm 0.02 \\
\text { (47\% removed by albumin } \\
\text { washing) }\end{array}$ & \\
\hline
\end{tabular}

Lipids were extracted from untreated and phospholipase $A_{2}$-treated membranes $(5 \mu \mathrm{g} / \mathrm{mg}$ protein. $30^{\circ} \mathrm{C}$ for $15 \mathrm{~min}$ ). Thin-layer chromatograms of membrane lipids (about $100 \mu \mathrm{g}$ applied in each track) were run in $\mathrm{CHCl}_{3}: \mathrm{CH}_{3} \mathrm{OH}: \mathrm{H}_{2} \mathrm{O}(65: 25: 4, \mathrm{vol} / \mathrm{vol})$. The thin-layer plates were exposed to iodine vapor and the yellow stained spots of individual phospholipids were marked and scraped from the plate. Total phospholipid was determined by measuring the amount of $\mathrm{P}_{\mathrm{i}}$ in the membranes and the amount of each phospholipid was determined by measuring the amount of $\mathrm{P}_{\mathrm{i}}$ in the scraped spots (Böttcher et al., 1961). The results are means of duplicates. The experiments were replicated three times. N.D., not detected. 


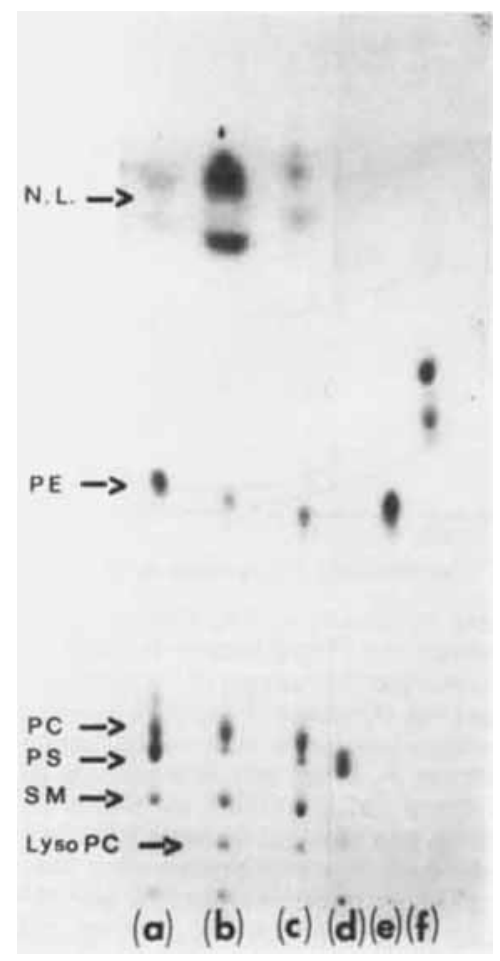

FIG. 4. Thin-layer chromatogram of membrane lipids from native and phospholipase $A_{2}$-treated microsomal membranes. About $35 \mu \mathrm{g}$ of lipid were applied to each track. (a) Lipids from native microsomal membranes. (b) Lipids from microsomal membranes after $15 \mathrm{~min}$ incubation with phospholipase $A_{2}(5 \mu \mathrm{g} / \mathrm{mg}$ protein) and not albumin washed. (c) Lipids from microsomal membranes incubated with phospholipase $\mathrm{A}_{2}$ as indicated before, but after $2.5 \%$ albumin washing. (d), (e), (f) Standard lipids: (d) phosphatidylserine; (e) phosphatidylethanolamine; (f) cerebrosides. It is important to observe that lysophosphatidylcholine is detectable even after albumin washing of phospholipase $A_{2}$-treated membranes. Identification of spots was carried out after specific detection with ninhydrin and phosphorus reagents. Lyso PC, lysophosphatidylcholine; SM, sphingomyelin; PS phosphatidylserine; PC, phosphatidylcholine; PE, phosphatidylethanolamine; NL, neutral lipids.

Incubation of the membranes with $1.5 \mu \mathrm{g} / \mathrm{mg}$ protein Vipera russeli phospholipase $\mathrm{A}_{2}$ results in a loss of over $90 \%$ of the original specific $\left[{ }^{3} \mathrm{H}\right]$ spiperone binding. Subsequent washing of the membranes with $2.5 \%$ bovine serum albumin does not restore $\left[{ }^{3} \mathrm{H}\right]$ spiperone specific or stereospecific binding, which probably reflects an irreversible destruction of the receptor by the enzyme action. Inclusion of albumin in the medium completely prevents the inhibitory effect of phospholipase $\mathrm{A}_{2}$ on $\left[{ }^{3} \mathrm{H}\right]$ spiperone binding activity of the membrane. However, at this enzyme concentration, in the presence of albumin, we still observe a hydrolysis of membrane phospholipids (about 28\%) to an extent similar to that obtained in the absence of albumin (Table 2).

The effect on the membrane of lysophosphatidylcholine, one of the hydrolysis products of phospholipase $A_{2}$, was also investigated. Lysophospha- tidylcholine added to the membranes inhibits $\left[{ }^{3} \mathrm{H}\right]$ spiperone specific and stereospecific binding to microsomal membranes, and the inhibition is proportional to the concentration of added lysophosphatidylcholine (Fig. 5). For $150 \mu \mathrm{g}$ of lysophosphatidylcholine added, we observe a decrease of $53 \%$ in stereospecific binding, while for $300 \mu \mathrm{g}$ of lysophospholipid added, a decrease of about $78 \%$ stereospecific binding is found (Table 3 ). There is no significant solubilization of membrane protein in the concentration range of added lysophosphatidylcholine, and we were unable to detect any $\left[{ }^{3} \mathrm{H}\right]$ spiperone binding activity in the supernatants. As shown in Fig. 6, lysophosphatidylcholine has an effect on $\left[{ }^{3} \mathrm{H}\right]$ spiperone binding activity quite similar to that of phospholipase $A_{2}$. However, this inhibitory effect is reversed by defatted serum albumin washing (Table 3 ). The percentage of $\left[{ }^{3} \mathrm{H}\right]$ spiperone stereospecific binding that can be recovered after removing lysolecithin by albumin washing depends on the quantity of lysophospholipid added (Table 3).

Lack of solubilizing effect of phospholipase $A_{2}$ on dopamine receptor from microsomal membranes

Since phospholipase $A_{2}$ digestion products (lysophospholipids and fatty acids) are known to possess surface active properties and to act as solubilizing agents, an attempt was made to quantitate the receptor concentration in the soluble and particulate fractions following treatment of membranes with the enzyme. No detectable solubilization of membrane-bound receptor is evident upon phospholipase $\mathrm{A}_{2}$ treatment. Although some binding activity is found in the soluble fraction, it does not display specificity and it is in no instance higher than that found in the soluble fraction of the control membranes.

The results in Table 4 show that digestion of the membranes with phospholipase after formation of the $\left[{ }^{3} \mathrm{H}\right]$ spiperone receptor complex due to pre-incubation of the membranes with $\left[{ }^{3} \mathrm{H}\right]$ spiperone results in loss of bound radioactivity, but the bound radioactivity recovered in the soluble fraction is comparable to that with control membranes.

\section{Effect of addition of endogenous lipids on $\left[{ }^{3} \mathrm{H}\right]$ spiperone binding}

The effect of the addition of lipid isolated from the membranes on the binding of $\left[{ }^{3} \mathrm{H}\right]$ spiperone by caudate nucleus microsomal membranes treated with phospholipase $\mathbf{A}_{2}$ was analysed. Sonicated liposomes prepared with lipids extracted from microsomal membranes were added to membranes which had been pretreated with phospholipase, to determine whether the loss of $\left[{ }^{3} \mathrm{H}\right]$ spiperone binding activity could be restored by the added lipids (Fig. 7). The addition of lipids to pretreated membranes induces only a very slight increase in total and spe- 
TABLE 2. Effect of washing with defatted bovine serum albumin on $\left[{ }^{3} \mathrm{H}\right]$ spiperone binding by caudate nucleus microsomal fraction treated with phospholipase $\mathrm{A}_{2}$

\begin{tabular}{|c|c|c|c|c|}
\hline & \multicolumn{3}{|c|}{$\begin{array}{l}{\left[{ }^{3} \mathrm{H}\right] \text { Spiperone bound }} \\
\text { (fmol } \cdot \mathrm{mg}^{-1} \text { protein) }\end{array}$} & \multirow{2}{*}{$\begin{array}{l}\text { Phospholipid content } \\
\text { (mg } \cdot \mathrm{mg}^{-1} \text { protein) }\end{array}$} \\
\hline & Total & Specific & Stereospecific & \\
\hline \multirow{3}{*}{$\begin{array}{l}\text { 1. Native membranes } \\
\text { 2. Membranes }+\mathrm{PL} \mathrm{A}_{2} \\
\text { (not albumin washed) } \\
\text { Control membranes }\end{array}$} & 475 & 374 & 307 & 0.955 \\
\hline & 107 & 16 & 4 & 0.964 \\
\hline & 376 & 298 & 243 & 0.945 \\
\hline \multirow{2}{*}{$\begin{array}{l}\text { 3. Membranes }+ \text { PL } \mathrm{A}_{2} \\
\text { (washed with } 2.5 \% \text { albumin) } \\
\text { Control membranes } \\
\text { (washed with } 2.5 \% \text { albumin) }\end{array}$} & 30 & 11 & 4 & 0.737 \\
\hline & 257 & 203 & 173 & 0.907 \\
\hline \multirow{2}{*}{$\begin{array}{l}\text { 4. Membranes }+ \text { PL } A_{2} \\
+ \text { albumin } \\
\text { (washed with } 2.5 \% \text { albumin) } \\
\text { Control membranes }+ \text { albumin } \\
\text { (washed with } 2.5 \% \text { albumin) }\end{array}$} & 222 & 162 & 159 & 0.656 \\
\hline & 244 & 192 & 172 & 0.830 \\
\hline
\end{tabular}

The microsomal membranes $(1.0 \mathrm{mg}$ protein $/ \mathrm{ml})$ were incubated with $1.5 \mu \mathrm{g} / \mathrm{mg}$ protein phospholipase $\mathrm{A}_{2}$ (Vipera russeli) in the absence and in the presence of albumin, in $3.6 \mathrm{ml} 25 \mathrm{mM}$ Tris-maleate buffer ( $\mathrm{pH} \mathrm{7.0)}$ containing $2 \mathrm{mM} \mathrm{CaCl}$, at $30^{\circ} \mathrm{C}$, for $15 \mathrm{~min}$, as described in Materials and Methods. The concentration of free $\left[{ }^{3} \mathrm{H}\right]$ spiperone used in the assay was $0.26 \mathrm{nM}$. The results are means of triplicate determinations in a representative of four experiments with standard errors varying less than $\pm 6 \%$.

cific $\left[{ }^{3} \mathrm{H}\right]$ spiperone binding (Fig. 7), but induces a relatively large increase in both types of $\left[{ }^{3} \mathrm{H}\right]-$ spiperone binding in untreated membranes (Fig. 7). However, it was not possible to demonstrate a successful reconstitution of stereospecific binding ac-

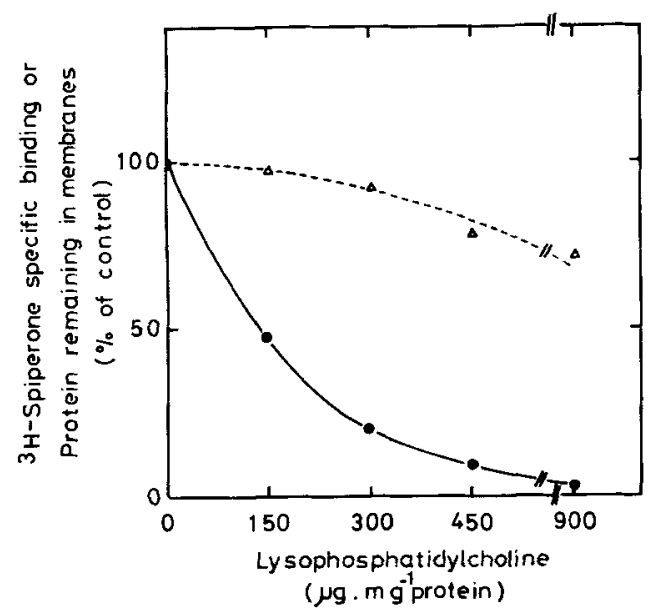

FIG. 5. Inactivation of $\left[{ }^{3} \mathrm{H}\right]$ spiperone specific binding by treatment of caudate nucleus microsomal membranes with $L-\alpha$-lysophosphatidylcholine (lysolecithin). A suspension of membranes $\left(1 \mathrm{mg} / \mathrm{ml}\right.$ protein) was incubated at $30^{\circ} \mathrm{C}$ for 15 min with different concentrations of lysophosphatidylcholine and then with $\left[{ }^{3} \mathrm{H}\right]$ spiperone $(0.2 \mathrm{nM})$ in the presence of $10^{-6}$ $M(+)$ - or (-)-butaclamol. Specific binding was measured by the filtration assay. $-\left[{ }^{3} \mathrm{H}\right]$ Spiperone specific binding expressed as percentage of control; $\triangle---\triangle$, protein remaining in the membrane after treatment with lysophosphatidylcholine. Values are the means of triplicate determinations from one of two experiments with standard errors varying less than $\pm 5 \%$. tivity following addition of lipid to either untreated or phospholipase $\mathrm{A}_{2}$-treated microsomal membranes, which indicates that we have not restored a functional dopamine receptor.

In another series of experiments, we analysed the $\left[{ }^{3} \mathrm{H}\right]$ spiperone binding capacity of endogenous lipids (Fig. 8). Multilamellar liposomes were prepared with lipids extracted from microsomal membranes, and $\left[{ }^{3} \mathrm{H}\right]$ spiperone binding to the liposomes was determined in the presence of $(+)$ - and $(-)$ butaclamol. We observed a binding of $\left[{ }^{3} \mathrm{H}\right]$ spiperone to the liposomes which is equally displaceable by $(+)$ - or (-)-butaclamol, that is, the lipid fraction does not display stereospecific binding of $\left[{ }^{3} \mathrm{H}\right]$ spiperone. Nevertheless, about $500 \mathrm{fmol}$ of $\left[{ }^{3} \mathrm{H}\right]$ spiperone are bound per $\mathrm{mg}$ of lipid.

\section{DISCUSSION}

The results show that treatment of caudate nucleus microsomal membranes with trypsin and phospholipase $\mathrm{A}_{2}$ (Vipera russeli) leads to inhibition of $\left[{ }^{3} \mathrm{H}\right]$ spiperone binding activity and that neuraminidase has no effect. In the first $5 \mathrm{~min}$ of enzymatic treatment, $\left[{ }^{3} \mathrm{H}\right]$ spiperone binding decreases from $360 \mathrm{fmol} / \mathrm{mg}$ protein to $66 \mathrm{fmol} / \mathrm{mg}$ protein in the presence of trypsin $(10 \mu \mathrm{g} / \mathrm{mg}$ protein $)$, and from $360 \mathrm{fmol} / \mathrm{mg}$ protein to $116 \mathrm{fmol} / \mathrm{mg}$ protein due to phospholipase $A_{2}(5 \mu \mathrm{g} / \mathrm{mg}$ protein) treatment. The effect of phospholipase $\mathrm{A}_{2}$ on membrane phospholipid hydrolysis closely correlates with the inactivation of dopamine receptor activity. The phospholipase effect is time- and concentration-dependent, and a maximal inhibitory effect is detectable in the 
TABLE 3. Effect of defatted albumin washing on $\left[^{3} H\right]$ spiperone stereospecific binding by caudate nucleus microsomal membranes pretreated with lysophosphatidylcholine

\begin{tabular}{|c|c|c|c|c|}
\hline & \multicolumn{2}{|c|}{$\begin{array}{c}{\left[{ }^{3} \mathrm{H}\right] \text { Spiperone stereospecific binding }} \\
\left(\mathrm{fmol} \cdot \mathrm{mg}^{-1} \text { protein }\right)\end{array}$} & \multicolumn{2}{|c|}{$\begin{array}{l}\text { Phospholipid content } \\
\left(\mathrm{mg} \cdot \mathrm{mg}^{-1} \text { protein) }\right.\end{array}$} \\
\hline & $\begin{array}{l}\text { Before albumin } \\
\text { washing }\end{array}$ & $\begin{array}{l}\text { After albumin } \\
\text { washing }\end{array}$ & $\begin{array}{l}\text { Before albumin } \\
\text { washing }\end{array}$ & $\begin{array}{l}\text { After albumin } \\
\text { washing }\end{array}$ \\
\hline Native membranes & 388 & & 0.978 & \\
\hline Control membranes & 272 & 173 & 0.969 & 0.907 \\
\hline Membranes + lyso PC $150 \mu \mathrm{g}$ & $128(47 \%)$ & $211(122 \%)$ & 1.086 & 0.923 \\
\hline + lyso PC $300 \mu \mathrm{g}$ & $60(22 \%)$ & $129(75 \%)$ & 1.356 & 1.033 \\
\hline + lyso $\mathrm{PC} 450 \mu \mathrm{g}$ & $17(6 \%)$ & $57(33 \%)$ & 1.776 & 0.937 \\
\hline
\end{tabular}

The membranes (about $1 \mathrm{mg}$ protein/ml) were incubated with the indicated concentrations of lysophosphatidylcholine (lyso PC) per mg protein, in $25 \mathrm{mM}$ Tris-maleate buffer ( $\mathrm{pH} 7.0)$ containing $2 \mathrm{mM} \mathrm{CaCl}_{2}$, at $30^{\circ} \mathrm{C}$ for $15 \mathrm{~min}$. Control membranes were incubated in the same conditions except that no lysophosphatidylcholine was added. After sedimentation of membranes an aliquot was taken for binding assay and phosphorus analysis. The remaining membranes were washed with $2.5 \%$ defatted bovine serum albumin and then with buffer. The final pellet, resuspended in TEAN buffer, was assayed for $\left[{ }^{3} \mathrm{H}\right]$ spiperone binding $(0.2 \mathrm{n} M)$ and phosphorus content. The values in parentheses represent the percentage of the control membranes in each case. The results are means of triplicate determinations in a representative of three experiments with standard errors varying less than $\pm 5 \%$.

first 15 min of enzymatic treatment at a phospholipase $A_{2}$ concentration of $5 \mu \mathrm{g} / \mathrm{mg}$ membrane protein, when about $56 \%$ of phospholipid hydrolysis has taken place. The phospholipase $A_{2}$ treatment decreases the $B_{\max }$ from $388 \pm 9.2 \mathrm{fmol} / \mathrm{mg}$ protein to $52 \pm 7.8 \mathrm{fmol} / \mathrm{mg}$ protein after phospholipase treatment, but does not significantly change the $K_{\mathrm{D}}$ value. The phospholipase inhibitory effect of $\left[{ }^{3} \mathrm{H}\right]$ spiperone binding is mimicked by added lysophosphatidylcholine. Thus, the inhibition of

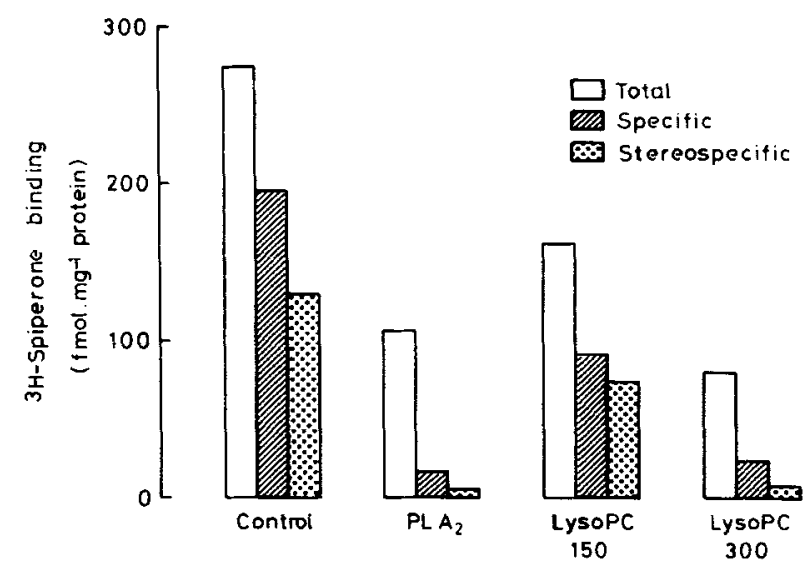

FIG. 6. Comparison between the effects of added lysophosphatidylcholine and phospholipase $A_{2}$ treatment $(5 \mu \mathrm{g} / \mathrm{mg}$ of protein for $15 \mathrm{~min}$, at $30^{\circ} \mathrm{C}$ ) on $\left[{ }^{3} \mathrm{H}\right]$ spiperone binding to $\mathrm{mi}-$ crosomal membranes. Aliquots of membrane preparations were incubated with different concentrations of $L-\alpha-\mid y s o-$ phosphatidylcholine (150 $\mu \mathrm{g}$ and $300 \mu \mathrm{g} / \mathrm{mg}$ protein) at $30^{\circ} \mathrm{C}$ for $15 \mathrm{~min}$ as described in Materials and Methods. The treated membranes were then assayed for $\left[{ }^{3} \mathrm{H}\right]$ spiperone binding $\left(0.2 \mathrm{nM}\right.$ final concentration) in the presence of $10^{-6}$ $M(+)$ - and (-)-butaclamol. A control assay was carried out in the same conditions, except for added L- $\alpha$-lysophosphatidylcholine and phospholipase $A_{2}$. Values are the means of triplicate determinations from one of two experiments which varied less than $8 \%$. Open bars, total binding; hatched bars, specific binding; dotted bars, stereospecific binding. Lyso PC, lysophosphatidylcholine. $\left[{ }^{3} \mathrm{H}\right]$ spiperone specific binding by membranes treated with phospholipase $A_{2}$ may be caused by the accumulation of lysophosphatides and fatty acids produced by enzymatic reaction, rather than by the destruction of membrane phospholipids per se. A restitution of receptor binding activity could not be obtained by the addition of endogenous lipids to phospholipase-treated membranes, although total $\left[{ }^{3} \mathrm{H}\right]$ spiperone binding is slightly increased (Fig. 7). Therefore, stereospecific binding is a subtle property of the receptor not easily recovered once it is lost.

The inhibitory action of phospholipase $A_{2}$ on

TABLE 4. $\left[{ }^{3} H\right]$ Spiperone microsomal membranes prelabelling followed by phospholipase $A_{2}$ treatment (5 $\mathrm{\mu g} / \mathrm{mg}$ protein for $15 \mathrm{~min}$ )

\begin{tabular}{lcc}
\hline & \multicolumn{1}{c}{$\begin{array}{c}{\left[{ }^{3} \mathrm{H}\right] \text { Spiperone }} \\
\text { specific binding } \\
\left(\mathrm{fmol} \cdot \mathrm{mg}^{-1} \text { protein }\right)\end{array}$} \\
\cline { 2 - 3 } & Membranes & $\begin{array}{c}\text { Soluble } \\
\text { fraction }\end{array}$ \\
\hline Native membranes & 672 & - \\
Control & 564 & N.D. \\
PL $\mathrm{A}_{2}$ treated & 46 & N.D. \\
Control + albumin washed & 399 & - \\
PL $\mathrm{A}_{2}$ treated + albumin washed & N.D. & - \\
\hline
\end{tabular}

Caudate nucleus microsomal membranes $(2 \mathrm{mg} / \mathrm{ml}$ protein) were prelabelled with $\left[{ }^{3} \mathrm{H}\right]$ spiperone ( $2 \mathrm{n} M$ final free concentration) in the presence of $10^{-6} M(+)$-, or (-)-butaclamol and incubated with phospholipase $\mathrm{A}_{2}(5 \mu \mathrm{g} / \mathrm{mg}$ protein), in the presence of $2 \mathrm{mM} \mathrm{CaCl}$, at $30^{\circ} \mathrm{C}$ for $15 \mathrm{~min}$, as described in Materials and Methods. After centrifugation at $100,000 \times g$ for $1 \mathrm{~h}$, the supernatants were assayed for bound $\left[{ }^{3} \mathrm{H}\right]$ spiperone by the charcoal adsorption method for soluble receptor (Wheatley and Strange, 1983). The pellets were suspended in $10 \mathrm{~m} M$ Tris-maleate ( $\mathrm{pH} 7.0)$ and were washed in an excess of buffer. The final pellets were suspended in TEAN buffer $(\mathrm{pH} 7.4)$ and were analysed for retained radioactivity by the filtration method (Seeman et al., 1975). The results are means of triplicates with standard errors varying less than $\pm 10 \%$. N.D., not detected. 

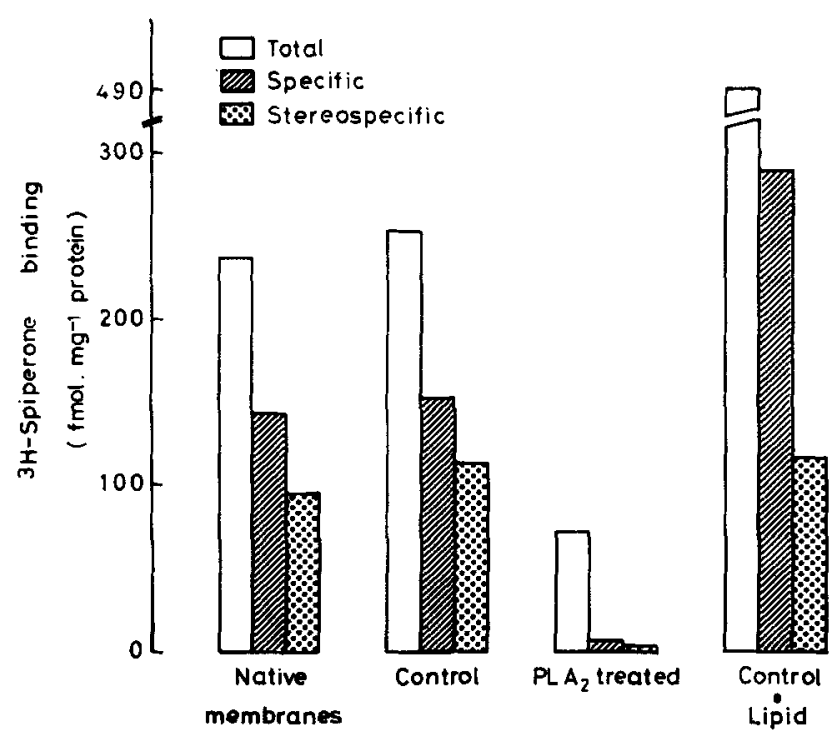

$\left[{ }^{3} \mathrm{H}\right]$ spiperone specific and stereospecific binding to caudate nucleus microsomal membranes may result directly from disruption of important lipid-protein interactions, or indirectly from a subsequent action of the hydrolysis products that can act as structuredisturbing agents or even as detergents on biological membranes (Blume et al., 1976; Weltzien, 1979). Lysophospholipids resulting from phospholipase $\mathrm{A}_{2}$ action, namely lysophosphatidylcholine, could not be completely removed from the membrane, even after defatted bovine serum albumin washing of the treated membranes. Under these conditions, only $47 \%$ of lysophosphatidylcholine is removed from the membrane. A high sensitivity of receptor binding capacity to phospholipase $\mathrm{A}_{2}$ has

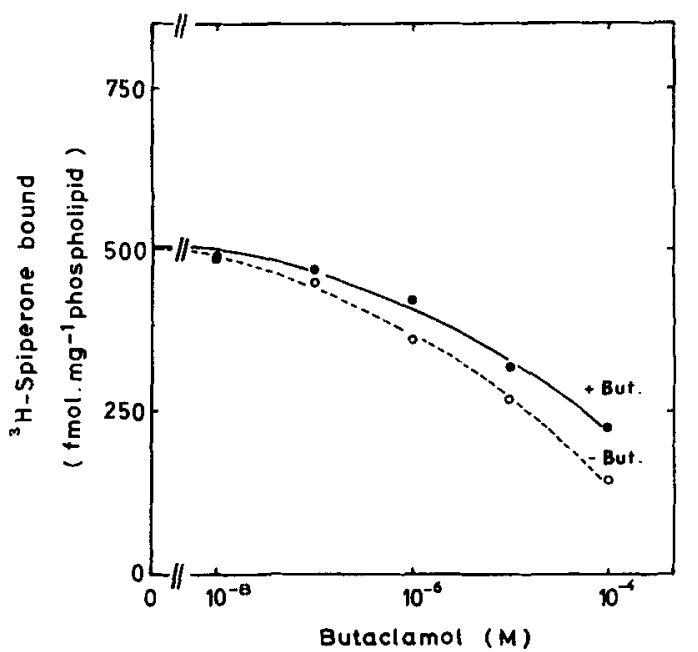

FiG. 8. $\left[{ }^{3} \mathrm{H}\right]$ Spiperone binding to the lipids isolated from caudate nucleus microsomal fraction. Multilamellar liposomes were prepared from lipids extracted from microsomal membranes, as described in Materials and Methods. $\left[{ }^{3} \mathrm{H}\right]$ Spiperone binding ( $\mathrm{n} M$ final concentration) was analysed in the presence of different concentrations of $(+)$ - and (-)-butaclamol ranging from $10^{-8}$ to $10^{-4} \mathrm{M}$.
FIG. 7. Effect of lipid addition on $\left[{ }^{3} \mathrm{H}\right]$ spiperone binding to microsomal membranes. Membranes pretreated with phospholipase $A_{2}(5 \mu \mathrm{g} / \mathrm{mg}$ protein) for $15 \mathrm{~min}$ at $37^{\circ} \mathrm{C}$ were incubated with sonicated liposomes as described in Materials and Methods. Controls were carried out in the same conditions as treated membranes. $\left[{ }^{3} \mathrm{H}\right]$ Spiperone binding, at a free concentration of $0.2 \mathrm{nM}$, was assayed in the presence of $(+)$ - and $(-)$-butaclamol ( $1 \mu M$ final concentration). Open bars, total binding; hatched bars, specific binding; dotted bars, stereospecific binding. The control signifies membranes submitted to the procedure of phospholipase treatment, but in the absence of phospholipase.

been reported for opiate ( $\mathrm{Lin}$ and Simon, 1978; Lin et al., 1981), $\beta$-adrenergic (Limbird and Lefkowitz, 1976), acetylcholine (Andreasen et al., 1979), and gonadotropin (Azhar and Menon, 1976; Azhar et al., 1976) receptors. However, this inhibitory effect of phospholipase $A_{2}$ is reversed upon removal of phospholipid byproducts of the membrane by defatted serum albumin ( $\mathrm{Lin}$ and Simon, 1978; Lin et al., 1981). Under our experimental conditions, we could obtain neither a recovery of $\left[{ }^{3} \mathrm{H}\right]$ spiperone binding activity nor a complete removal of lysophosphatides after enzymatic treatment of the membranes. Thus, in the case of our study with dopamine receptors, following extensive hydrolysis of the membrane phospholipids (30\% of phospholipid hydrolysed by $0.5 \mu \mathrm{g}$ of phospholipase $\mathrm{A}_{2}$ for $5 \mathrm{~min}$ ), the level of unhydrolysed phospholipids in the membrane may be insufficient to maintain a native conformational state of the receptor, in the presence of the hydrolysis products which result from the enzyme treatment.

The inhibition of dopamine receptor activity caused by lysophosphatidylcholine, and the protective effect of albumin when present in the incubation medium containing the membranes and phospholipase $A_{2}$ (Table 2), strongly suggest that the phospholipid hydrolysis products in the membrane are directly involved in the alteration of $\left[{ }^{3} \mathrm{H}\right]-$ spiperone binding capacity. Addition of relatively low concentrations of lysophosphatidylcholine to the membranes mimics the effect of phospholipase $A_{2}$ (Fig. 6). However, this inhibitory effect can be reversed by defatted albumin washing of the membranes, which removes the excess of lysophosphatidylcholine taken up. This reversibility of the lysophosphatidylcholine effect suggests that lysophosphatides added and taken up by the membrane have a behaviour quite different from those produced by phospholipase $A_{2}$. The latter stick more 
tightly to the membrane, probably because they are a more integral part of the membrane than those added. The protective effect of albumin included in the incubation medium presumably is due to sequestering of the phospholipid hydrolysis products as fast as they are formed during incubation. It should be noted that about the same level of phospholipid hydrolysis occurs in the presence or in the absence of albumin. Solubilization of the membrane receptors by phospholipase $A_{2}$ treatment could explain the decrease in maximal number of binding sites caused by the phospholipase $A_{2}$ treatment of the membranes. However, we were unable to detect active solubilized dopamine receptors after enzyme treatment of the membranes, even in a situation in which the membranes were prelabelled with $\left[{ }^{3} \mathrm{H}\right]$ spiperone. Similar results have been recently reported by Rüegg et al. (1982) for brain opiate receptors. The lysophosphatides formed under these conditions may not reach a sufficiently high concentration to solubilize the receptors (Rüegg et al., 1982), and therefore they remain in the membrane structure, or the membrane dopamine receptors may actually be solubilized (Wheatley and Strange, 1983), but become inactive. This is unlikely because only a small loss of membrane protein is observed, which does not correlate with the loss of receptor activity by the membrane. It should also be pointed out that the molar ratio of membrane cholesterol to phospholipid increases following enzyme treatment, which may alter membrane fluidity (Blume et al., 1976) and, subsequently, affect the number of available $\left[{ }^{3} \mathrm{H}\right]$ spiperone binding sites. In any case, the inhibition produced by phospholipase $\mathrm{A}_{2}$ seems to be primarily caused by phospholipid hydrolysis end products associated to membrane components rather than the mere loss of the phospholipids from the membrane.

We found that $\left[{ }^{3} \mathrm{H}\right]$ spiperone is able to bind to membrane lipids (Fig. 8), as expected also from its partition coefficient (Leysen and Gommeren, 1981), but this binding is not stereospecific. Furthermore, addition of endogenous lipids to untreated and phospholipase $\mathrm{A}_{2}$-pretreated membranes, although it increases total and specific $\left[{ }^{3} \mathrm{H}\right]$ spiperone binding, was unable to restore stereospecific binding to phospholipase $A_{2}$-treated membranes or to influence the stereospecific binding of untreated membranes. Thus, the effect of phospholipase certainly is not due to any decreased specific $\left[{ }^{3} \mathrm{H}\right]$ spiperone binding by the lipid moiety of the membrane. The products of phospholipid hydrolysis, accumulated in the membrane, probably induced an irreversible change in dopamine receptor that could not be reversed by lipid addition to caudate nucleus membranes after phospholipase $\mathrm{A}_{2}$ treatment.

The results suggest that $\left[{ }^{3} \mathrm{H}\right]$ spiperone stereospecific binding is dependent upon integrity of both protein and phospholipids, that is, the dopamine receptors in caudate nucleus are membrane binding sites, probably protein in nature, which are closely associated with the lipid bilayer. The structure of the surrounding lipid environment can directly influence the properties of the dopamine receptor, since phospholipase $\mathrm{A}_{2}$ inhibition of the binding activity is due to alteration of the phospholipid components of the membrane, but lysophosphatides, and probably fatty acids, are also capable of influencing dopamine receptor regulation. Although information regarding possible functional effects of the lipids is not available, the findings suggest that localized changes in the membrane lipid environment could play some role in modulating dopamine receptor activity.

Acknowledgments: This work was supported by grants from the INIC, Portuguese Ministry of Education, and NATO (NATO Research Grant No. 1513).

\section{REFERENCES}

Agnew W. S. and Raftery M. A. (1979) Solubilized tetrodotoxin binding component from the electroplax of Electrophorus electricus. Stability as a function of mixed lipid detergent micelle composition. Biochemistry 18, 1912-1919.

Andreasen T. J., Doerge D. R., and McNamee M. G. (1979) Effects of phospholipase $A_{2}$ on the binding and ion permeability control properties of the acetylcholine receptor. Arch. Biochem. Biophys. 194, 468-480.

Azhar S. and Menon K. M. J. (1976) Gonadotropin receptors in plasma membranes of bovine corpus luteum. I. Effect of phospholipases on the binding of ${ }^{125}$ I-choriogonadotropin by membrane-associated and solubilized receptors. J. Biol. Chem. 251, 7398-7404.

Azhar S., Hajra A. K., and Menon K. M. J. (1976) Gonadotropin receptors in plasma membranes of bovine corpus luteum. II. Role of membrane phospholipids. J. Biol. Chem. $251,7405-7412$.

Bakardjieva A., Galla H. J., and Helmreich E. J. M. (1979) Modulation of the $\beta$-receptor adenylate cyclase interactions in cultured Chang liver cells by phospholipid enrichment. Biochemistry 18, 3016-3023.

Bangham A. D., De Gier J., and Greville G. D. (1967) Osmotic properties and water permeability of phospholipid liquid crystals. Chem. Phys. Lipids 1, 225-248.

Bartlett G. R. (1959) Phosphorus assay in column chromatography. J. Biol. Chem. 234, 466-468.

Blume A., Arnold B., and Weltzien H. U. (1976) Effects of a synthetic lysolecithin analog on phase transition of mixtures of phosphatidylethanolamine and phosphatidylcholine. FEBS Lett. 61, 199-202.

Böttcher C. J. F., van Gent C. M., and Pries C. (1961) A rapid and sensitive sub-microphosphorus determination. Anal. Chim. Acta 24, 203-204.

Chang H. W. and Bock E. (1979) Structural stabilization of isolated acetylcholine receptor: specific interaction with phospholipids. Biochemistry 18, 172-179.

Hajós F. (1975) An improved method for the preparation of synaptosomal fractions in high purity. Brain Res. 93, 485-489.

Heidmann T., Sobel A., and Changeux J. P. (1980) Conservation of the kinetic and allosteric properties of the acetylcholine receptor in its $\mathrm{Na}$ cholate soluble $9 \mathrm{~S}$ form: effect of lipids. Biochem. Biophys. Res. Commun. 93, 127-133.

Heron D. S., Shinitzky M., Hershkowitz M., and Samuel D. 
(1980) Lipid fluidity markedly modulates the binding of serotonin to mouse brain membranes. Proc. Natl. Acad. Sci. USA 77, 7463-7467.

Huang C. and Thompson T. E. (1974) Preparation of homogeneous, single-walled phosphatidylcholine vesicles, in Methods in Enzymology, Vol. 32 (Colowick S. P. and Kaplan N. O., eds), pp. 485-489. Academic Press, New York.

Huang T. C., Chen C. P., Wefler V., and Raftery A. (1961) A stable reagent for the Liebermann-Burchard reaction. Application to rapid serum cholesterol determination. Anal. Chem. 33, 1405-1407.

Laduron P. M. and llien B. (1982) Solubilization of brain muscarinic, dopaminergic and serotonergic receptors: a critical analysis. Biochem. Pharmacol. 31, 2145-2151.

Layne E. (1957) Spectrophotometric and turbidimetric methods for measuring proteins, in Methods in Enzymology, Vol. 3 (Colowick S. P. and Kaplan N. O., eds), pp. 447-451. Academic Press, New York.

Leysen J. E. and Gommeren W. (1981) Optimal conditions for $\left[{ }^{3} \mathrm{H}\right]$ apomorphine binding and anomalous equilibrium binding of $\left[{ }^{3} \mathrm{H}\right]$ apomorphine and $\left[{ }^{3} \mathrm{H}\right]$ spiperone to rat striatal membranes: involvement of surface phenomena versus multiple binding sites. $J$. Neurochem. 36, 201-219.

Leysen J. E and Van Gompel P. (1982) Effects of proteolytic enzymes and monovalent ions demonstrate protease-sensitive and protease-insensitive stereospecific binding sites on dopaminergic receptors in rat striatum. Biochem. Pharmacol. 31, 1343-1355.

Leysen J. E., Gommeren N., and Laduron P. M. (1978) Spiperone: a ligand of choice for neuroleptic receptors. 1. Kinetics and characteristics of in vitro binding. Biochem. Pharmacol. 27, 307-316.

Limbird L. E. and Lefkowitz R. J. (1976) Adenylate cyclasecoupled beta-adrenergic receptors: effect of membrane lipid-perturbing agents on receptor binding and enzyme stimulation by catecholamines. Mol. Pharmacol. 12, 559567.
Lin H. K. and Simon E. J. (1978) Phospholipase A inhibition of opiate receptor binding can be reversed by albumin. Nature 271, 383-384.

Lin H. K., Holland M. J. C., and Simon E. J. (1981) Characterization of phospholipase A inhibition of stereospecific opiate binding and its reversal by bovine serum albumin. J. Pharmacol. Exp. Ther. 216, 149-155.

Lowry O. H., Rosebrough N. J., Farr A. L., and Randall R. J. (1951) Protein measurement with the Folin phenol reagent. J. Biol. Chem. 193, 265-275.

Pasternak G. W. and Snyder S. H. (1974) Opiate receptor binding enzymatic treatments discriminate between agonist and antagonist interactions. Mol. Pharmacol. 10, 183-193.

Reed C. F., Swisher S. N., Marinetti G. V., and Eden E. G. (1960) Studies of the lipids of the erythrocyte. I. Quantitative analysis of the lipids of normal human red blood cells. J. Lab. Clin. Med. 56, 281-289.

Reed J. K. (1981) Modification of the tetrodotoxin receptor in Electrophorus electricus by phospholipase $\mathrm{A}_{2}$. Biochim. Biophys. Acta 646, 43-50.

Rüegg U. T., Cuenoud S., Fulpius B. W., and Simon E. (1982) Inactivation and solubilization of opiate receptors by phospholipase $\mathrm{A}_{2}$. Biochim. Biophys. Acta 685, 241-248.

Seeman P., Chau-Wong M., Tedesco J., and Wong K. (1975) Brain receptors for antipsychotic drugs and dopamine: direct binding assays. Proc. Natl. Acad. Sci. USA 72, 43764380.

Skipski V. P. and Barclay M. (1969) Thin-layer chromatography of lipids, in Methods in Enzymology, Vol. 14 (Colowick S. P. and Kaplan N. O., eds), pp. 530-598. Academic Press, New York.

Weltzien H. U. (1979) Cytolytic and membrane perturbing properties of lysophosphatidylcholine. Mol. Pharmacol. 12, 259-287.

Wheatley M. and Strange P. G. (1983) Characterisation of brain $\mathrm{D}_{2}$ dopamine receptors solubilised by lysophosphatidylcholine. FEBS Lett. 151, 97-101. 